\title{
Relations Among Monetary Aggregates
}

IN

RECENT YEARS greater attention has been given to the growth rates of various monetary aggregates as measures of the influence of stabilization actions on economic activity. Four of the most frequently discussed aggregates are the money stock (private demand deposits plus currency held by the public), money pltus time deposits, bank credit (total loans and investments of commercial banks), and the monetary base'. This note discusses briefly the principal factors influencing the growth of these aggregates over time and cites special considerations analysts must keep in mind in deriving conclusions from observed changes in the growth of these aggregates.

Expansion of the monetary base over periods of several months is dominated by the growth of Federal Reserve Credit and, therefore, is determined principally by changes in the Federal Reserve's holdings of U.S. Government Securities. It is generally agreed that, among the four major monetary aggregates, the Federal Reserve, through its open market operations, can exercise closest control over the monetary base.

The money stock, money plus time deposits, and bank credit can all be related to the monetary base through "monetary multipliers." 2 These multipliers summarize all of the economic and institutional factors which link changes in the monetary base to changes in the other three aggregates. For the past two years the monetary base has grown at a rather steady 6 per cent annual rate. During the same period, money, money plus time deposits, and bank credit each have grown, for short periods of a few months, slower than the monetary base, while in other periods they have grown much faster than the base.

In recent years, changes in the growth rate of bank credit have been more highly correlated with changes

\footnotetext{
1See "The Monetary Base - Explanation and Analytical Use," in the August 1968 issue of the Review.

2For a thorough presentation of one theoretical model relating money, money plus time deposits, and bank credit to the monetary base, see A. E. Burger, "A Summary of the Brunner-Meltzer Non-Linear Money Supply Hypothesis," Working Paper No. 7, Federal Reserve Bank of St. Louis, Jantary 1969.
}

in the growth of money plus time deposits than wit changes in the growth of the money stock, because 0 the effects of Regulation $Q$ ceilings on the interes rates banks are permitted to pay on time deposits The following discussion will illustrate how change in the money stock, in money plus time deposits, ani in bank credit are influenced by factors other than thi monetary base.

In recent years, there have been two principa factors influencing the growth rates of money, mone plus time deposits, and bank credit relative to eacl other and relative to the base. These are fluctuation in U.S. Government deposits at commercial bank and the growth of time deposits relative to demani deposits.

\section{U.S. Government Deposits}

U.S. Government deposits are a direct substitut (in an accounting sense as a liability of commercia banks) for private demand deposits. Banks whicl are members of the Federal Reserve System are $1 \mathrm{t}$ quired to hold the same minimum reserve balance against U.S. Government deposits as against privat demand deposits.

As individuals and corporations pay taxes (includ ing withheld taxes) or purchase newly issued Treas ury securities, their demand deposit (checking ac count) balances decrease and U.S. Governmen deposits increase. Then as the Government spend its balances decrease and private balances increase Since U.S. Government deposits are not defined a part of the money stock, private money decreases a Government balances are built up, and increases a Government balances are run down, other thing equal. In recent years, the Government's balances a commercial banks have ranged from as low as $\$$ billion to as high as $\$ 9$ billion within a few month time.

On average over the past twenty years, the mone stock has increased a little more than $\$ 2.5$ billio for every $\$ 1$ billion increase in the monetary bast In the last two years the base has been increasin about $\$ 1$ billion every three months, or at about 6 per cent annual rate. However, there have bee several instances in recent years when money ir creased very little for a few months while Goverr 
ment balances were being built up, even though the monetary base was continuing to grow rapidly. In subsequent months, as Government balances were reduced, the growth of money accelerated to rates much faster than the growth rate of the base. Over the period as a whole, the growth rate of money averaged very close to the growth rate of the base.

\section{Time Deposits}

Changes in time deposits at commercial banks also cause an offsetting change in private demand deposits, but not on a one to one basis. Banks are required to hold reserve balances against both time and demand deposits, but the reserve requirement percentages are much lower for time deposits than for demand deposits. A dollar of reserves can "support" a much larger volume of time deposits than demand deposits. If the growth of time deposits accelerates relative to the growth of total reserves, the growth of total demand deposits will decrease (assuming excess reserves are constant). That is, a larger proportion of total reserves becomes "required" behind the increased time deposits, so there are less "reserves available" to support demand deposits.

In the 1960's time deposits at commercial banks have grown much faster on average than demand deposits. Therefore, an increasing proportion of total reserves have been required behind time deposits, leaving a diminishing proportion of total reserves available for demand deposits. This upward trend of time deposits has altered the multiplier relationship between the monetary base and money, and between the base and money plus time deposits. Since 1960 the multiplier relation between the base and money has trended downward, resulting in a somewhat slower average growth rate for money than for the base. At the same time, the multiplier between the base and money plus time deposits has trended upwards, resulting in a faster average growth rate for money plus time deposits than for the base.

There have been at least three distinct instances in the past three years in which the growth rate of time deposits has declined sharply relative to the growth rate of demand deposits. ${ }^{3}$ As the growth of time deposits declined, reserves which otherwise would have been held as required reserves behind time deposits were "released" and became "available"

3 Specifically, in the fall of 1966, spring of 1968, and from December 1968 to the present, the growth of time deposits slowed significantly relative to the growth of demand deposits. for demand deposits. Consequently, the sum of private and Government demand deposits was able to increase at rates faster than the growth rates of reserves and base money. (However, total deposits declined in these instances). In each of these cases the declining growth rate of time deposits (an absolute decline of time deposits in two of the instances) was directly attributable to rapid increases in market interest rates relative to the Regulation $Q$ ceiling interest rates banks are permitted to pay on time deposits.

The demand for time deposits by individuals and businesses is positively related to the yield on time deposits and negatively related to the yield on substitute earning assets, such as savings and loan shares, mutual savings bank deposits, Treasury bills, and commercial paper. When banks are offering to pay the ceiling rates permitted by Regulation $Q$ and are prevented from offering higher yields even though the yields on substitute assets are continuing to rise, the demand for time deposits declines as does the outstanding volume (or growth rate) of time deposits. In such circumstances, the growth of time deposits is determined by changes in the demand for them, since banks are willing to accept all deposits at the ceiling rates. Consequently, the decreasing growth rates of money plus time deposits, which occurred in the three above-mentioned instances when banks' offering rates on time deposits were constrained by the ceiling rates, were paralleled by falling demand for money plus time deposits.

\section{Summary}

Prediction of the effects of changes in the growth rate of a monetary aggregate on economic activity requires knowledge regarding the relative movements in the supply of and demand for the asset. Thus, when an analyst concludes that an acceleration in the growth rate of money will have expansionary effects on total spending in the economy, he is indicating that the supply of money is increasing relative to the demand for money to hold.

In the above-mentioned cases, the behavior of interest rates is evidence that a decline in the demand for money plus time deposits accompanied the $o b$ served reduction in the growth of the quantity of money plus time deposits. Under such circumstances, it should not be concluded that the observed slower growth rate of money plus time deposits will have a contractionary effect on total spending, since there is no evidence indicating that the supply of money plus time deposits is decreasing relative to the demand.

JERRY L. JORDAN 